\title{
THE BIOLOGY OF SPECIES OF SEROLIS (CRUSTACEA, ISOPODA, FLABELLIFERA): REPRODUCTIVE BEHAVIOR OF SEROLIS POLARIS RICHARDSON, 1911
}

\author{
Received September 9, 1972
}

PLINIO SOARES MOREIRA

Instituto Oceanográfico da Universidade de São Pauzo

\section{SYNOPSIS}

An account based on observations of the reproductive behavior of Serolis polaris is presented. Correlative additional information obtained from the examination of a large number of preserved specimens is discussed. Both the pre-copulatory behavior, and the copulatory position are described. Pre-adult females show sexual escape behavior. The pair of pereopods II are the only clasping appendages utilized in copulation. They are especially morphologically structured to perform this function. Marks, cuts and sores may be produced on the females by the rubbing movements of the clasping pereopods. Experiments show that when mature, males and females do not ingest food. A full discussion of all these behavioral aspects connected with reproduction is provided.

\section{INTRODUCTION}

There are many accounts available dealing with different aspects of the biology of marine isopods (Howes, 1939; Forsman, 1944; Kjennerud, 1952; Bocquet, 1953; Kinne, 1954; Naylor, 1955; Bowman, 1960; Wolff, 1962; Do Chi, 1970 ; White, 1970; Jones, 1970; Fish, 1970).

However, in relation to the species of the genus Serolis, excepting exclusively systematic works, relatively few furnish biological information (Beddard, 1884; Sheppard, 1933; Moreira, 1966;1971a-b; 1973a-c; Hessler, 1967; 1970; Bastida \& Torti, 1970). These works give general information, or deal with particular features of the life cycle.

The aim of the present paper is to report the results of observations on the reproductive behavior, and specifical1y before and during copulation, of Serolis polaris. Additional correlative data obtained from the examination of a sizable number of preserved specimens are also presented, in order to augment the observations for a larger number of species.

PUBL. NO 337 DO INST. OCEAN. DA USP. 


\section{MATERIAL}

Live Serolis polaris were captured from the sea bottom by dredge hauls, and immediately kept in an aquarium containing water and substrate from the collecting site (i.e., off Cabo Frio, Rio de Janeiro, Brazil, Lat. 23002'S, Long. $43^{\circ} 00^{\prime} \mathrm{W}, 40 \mathrm{~m}$ depth).

The observations of the living animals were conducted aboard the R/V "Prof. W. Besnard", of the Instituto Oceanogräfico, University of São Paulo. The aquarium water temperature varied from $17.63-18.97^{\circ} \mathrm{C}$, the salinity was $35.80 \%$, and the dissolved oxygen concentration was $4.80 \mathrm{~m} 1 / 1$.

Table I gives details of the specimens of Serolis polaris captured. A total of 20 animals were maintained, of which 12 were gravid females, 2 preadult females and 6 adult males.

The additional correlative observations were made on material collected off southern Brazil (ISOTAN-DRAGA I Program of the author) by the R/V "Prof. W. Besnard" and "Emília", and off the Antarctic by the U.S. vessels "Eltanin", "Vema", and by the ice-breakers "Glacier", "Westwind" and "Eastwind". This material was under the care of Prof. R.J. Menzies. It was studied by the author while at the United States (Moreira,in press), through a grant provided by the U.S. National Science Foundation.

\section{RESULTS}

The captured adult males and females of Serolis polaris were normally slow and quiet animals, without vigorous or sudden rapid movements. They spent a great deal of their time in place,moving only occasionally. They walked slow $1 \mathrm{y}$ over the bottom. As soon as an adequate site was found, they partially bury themselves with rapid movements of the body into the substrate, to just beneath the surface.

The animals were scarcely distinguishable from the bottom. They are capable of undergoing color change by expansion and retraction of their chromatophores. It was shown that in mature males and females these chromatophoral movements act as cryptic protective coloration (Moreira, 1971b; 1974). Observations also showed that they are slightly more active at night than at daytime. Likewise, the males are slightly more active than the females.

The captured specimens offered an excellent opportunity for observing the reproductive behavior since the animals, by chance, were passing through this specific phase of their life cycle.

The females do not passively accept the males. The attempts were frustated chiefly because of the inadequate position of the males. If the males from the 
beginning do not clasp them correctly and firmly, the females will successful1y escape.

However, once the male assumes a position on the back of the female, he clasps her firmly between his second pair of pereopods, in such a manner that the marginal area of the female's first segment is held tightly between the propodus and dactylus of the male chela.

Figure 1 shows the ventral view of an adult male of Serolis schythei. The subchelate pereopod II (clasping appendage), as well as their relationship (size and position) to the remainder appendages of the body may be distinctly seen.

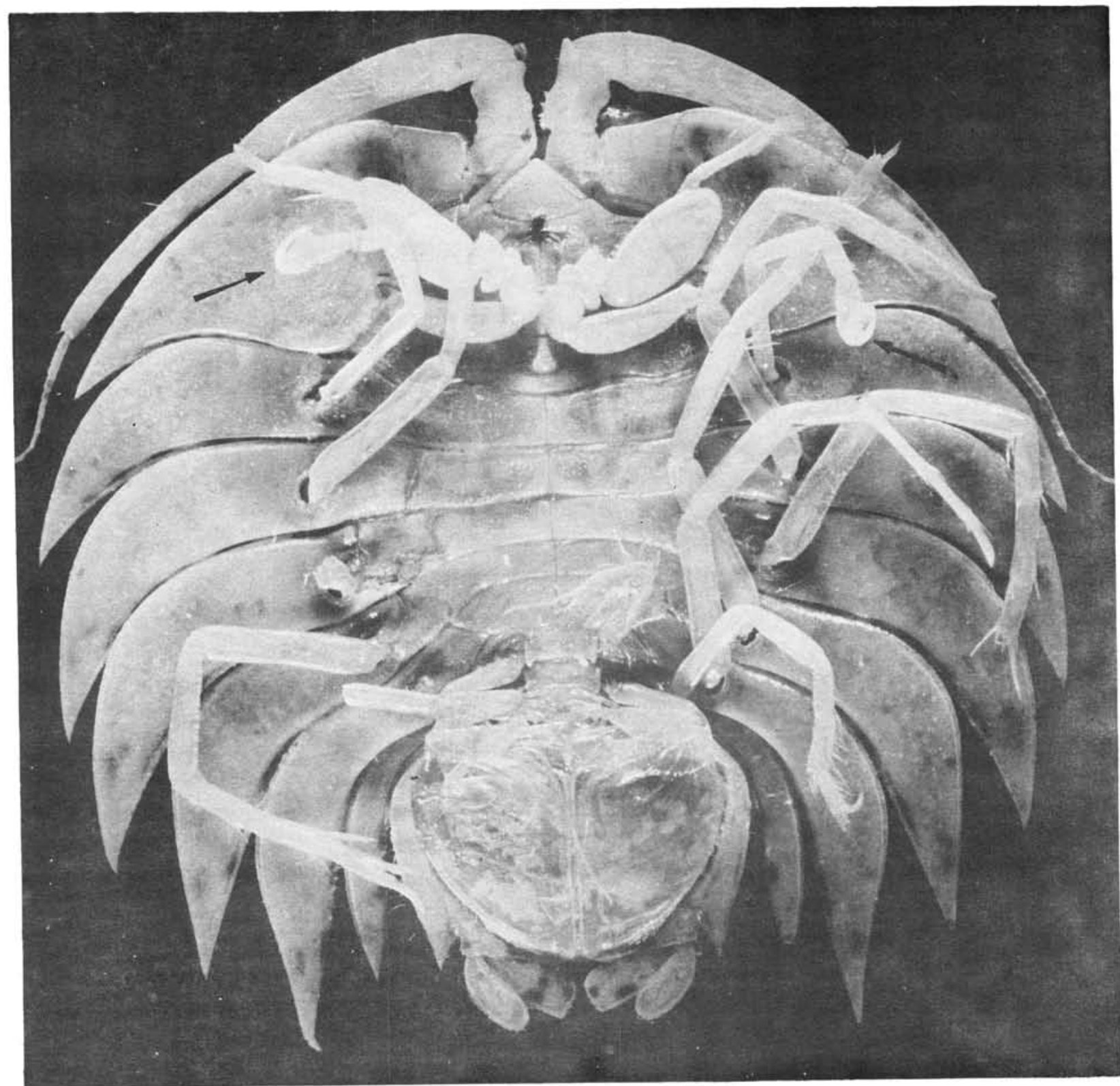

Fig. 1 - Serolis schythei, adult male, $31.0 \mathrm{~mm}$ long. Ventral view of whole animal showing specially the morphology, size and position of the subchelate pair of pereopod II (clasping appendage) in relation to remaining pereopods. 
Figure 2 shows details of both the pereopod I (which is similar in both sexes), and of the male and female pereopod II in a fully grown Serolis polita. It specially shows the shape of the articles (propodus and dactylus) making up the subchela, and the contrasting shape of these two articles in both male and female pereopod II.

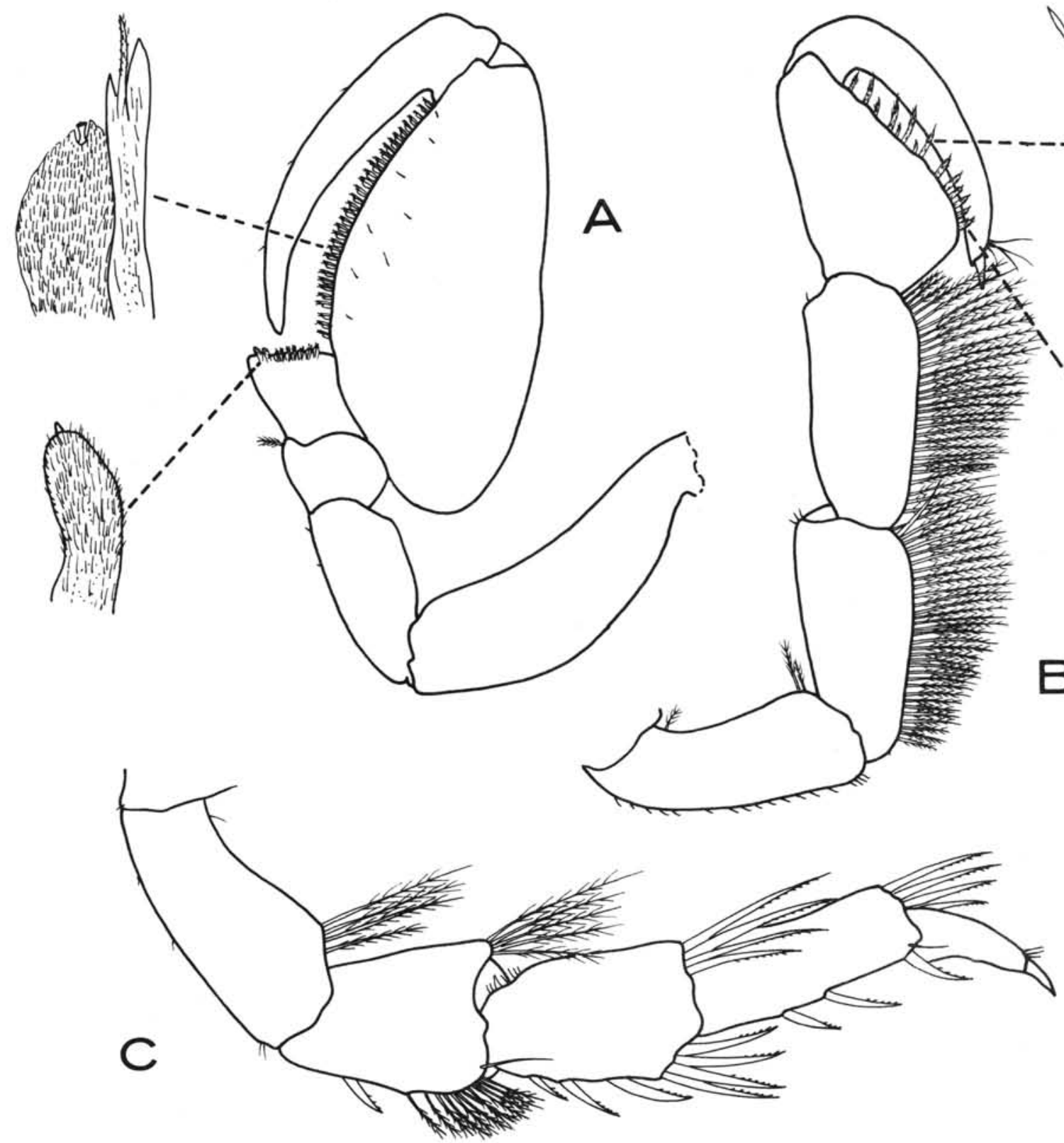

Fig. 2 - Serolis polita, adult male, $15.5 \mathrm{~mm}$ long, and adult female, $16.0 \mathrm{~mm} 1 \mathrm{ong}$. Details of both the male subchelate pereopods I and II and their setal pattern, and the female not subchelate pereopod II.

$A$ - pereopod I; $B$ - pereopod II; $C$ - pereopod II (female).

Figure 3 illustrates the pereopod II of adult males in some species of Serolis. Especially the variation in size, ornamentation and stoutness of the subchela should be noted. 

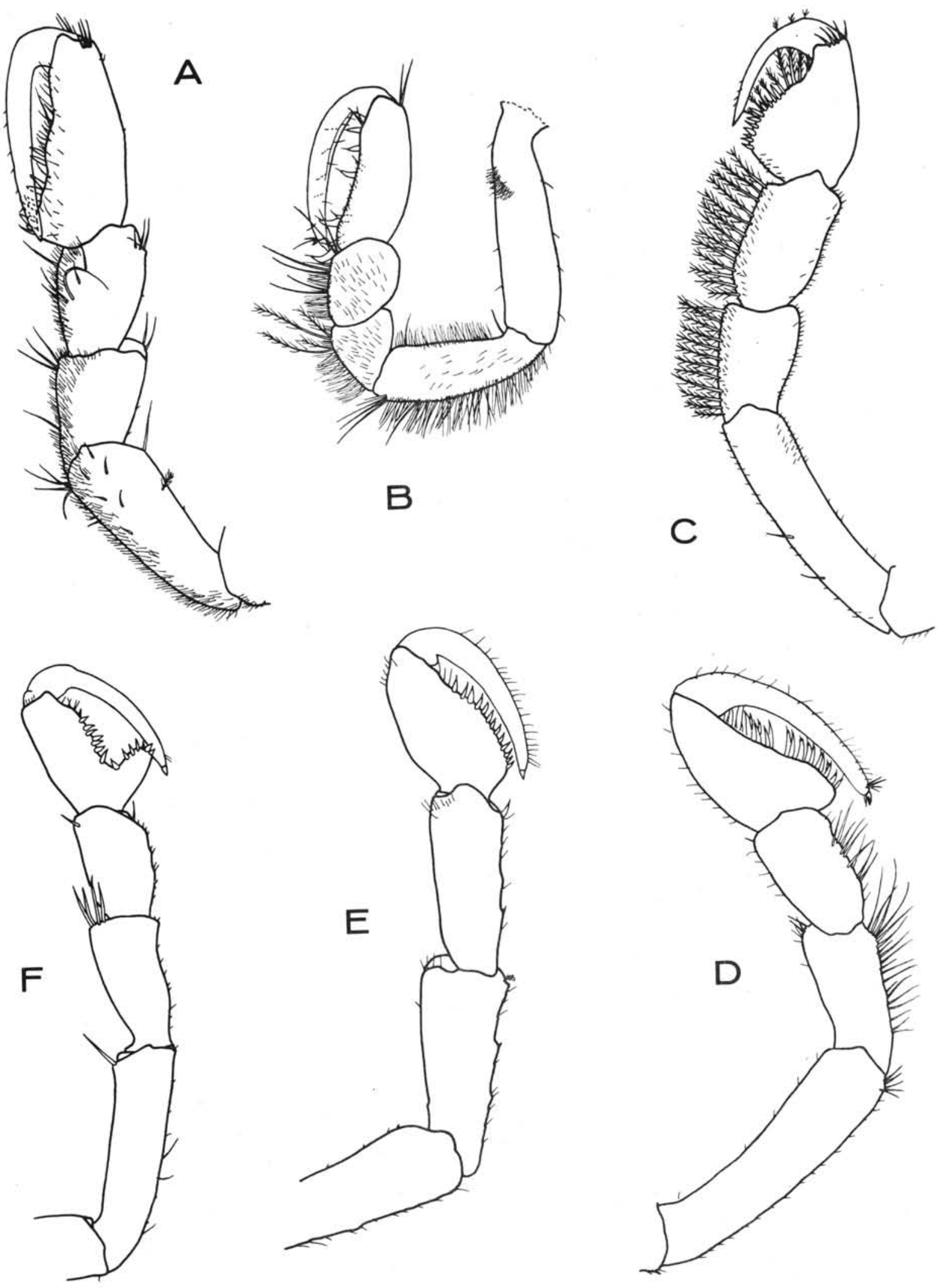

Fig. 3 - Clasping appendage (male pereopod II) in species of Serolis. Note different morphology of the subchela and variations in the ornamentation of the whole appendage.

A-Serolis pagenstecheri, $24.5 \mathrm{~mm} ; \quad B$ - Serolis completa, $4.0 \mathrm{~mm}$; C - Serolis neaera, $34.0 \mathrm{~mm}$; D-Serolis schythei, $23.5 \mathrm{~mm} ; E-$ Serolis trilobitoides, $52.0 \mathrm{~mm} ; F$ - Serolis bromleyana, $47.0 \mathrm{~mm}$. 
TABLE I - Serolis polaris collected off Rio de Janeiro, Lat. $23^{\circ} 02^{\prime} \mathrm{S}$ - Long. $43^{\circ} 00^{\prime} \mathrm{W}$.

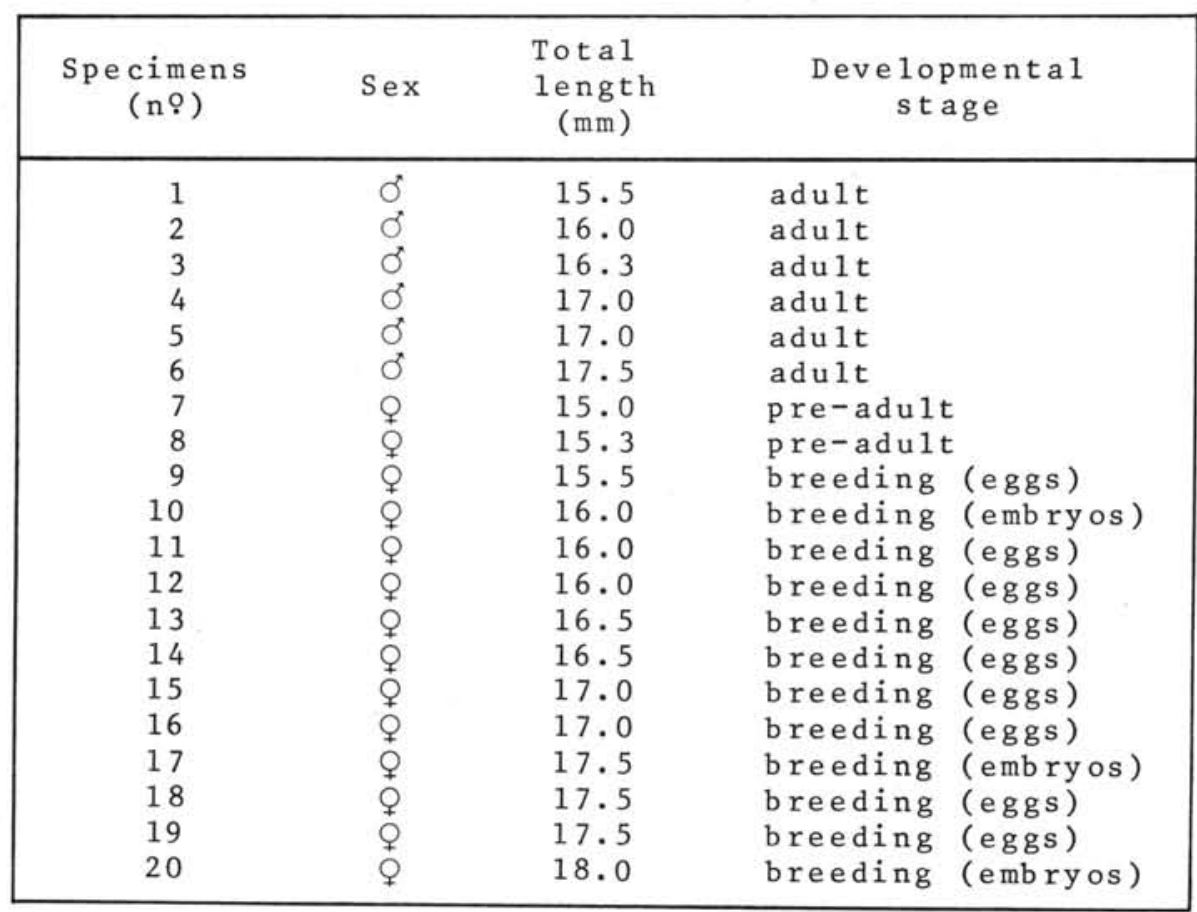

Figures 4 and 5 show the copulatory position in serolis polita. It is similar to that observed in both serolis polaris and Serolis beddardi. The male pereopod II clasping the lateral margins of the first segment of the female, as well as, that the remaining pereopods are not used in holding the female, may be clearly seen from the two figures. They also show that in the copulatory position the male lies on the dorsal side of the female with his head over her head, so that the male and female are orientated in a same direction.

The male clasps the female so firmly, that usually he marks her. Frequent1y the marginal areas of the pereonite I of the females, dorsally, as we 11 as ventrally, bear cuts, marks or anomalies produced by the rubbing movement of the subchela of the male pereopod II.

Figure 6 shows an example of the scars in a female of Serolis meridiona2is. Similar scars were also observed in specimens of Serolis schythei, Serolis bromleyana and Serolis neaera. Nordenstam (1933) mentioned them in Serolis paradoxa, Serolis latifrons, serolis pagenstecheri and serolis schythei.

The marks are highly variable in shape and extension. Sometimes appearing as smal1, oval shaped excavations (Nordenstam 1933, p. 41, fig. 9) and sometimes as large, elongate sores (Fig. 6). Often the dactylus makes a hole through the pereonite, as can be seen in a female serolis trizobitoides (Fig. 7). 

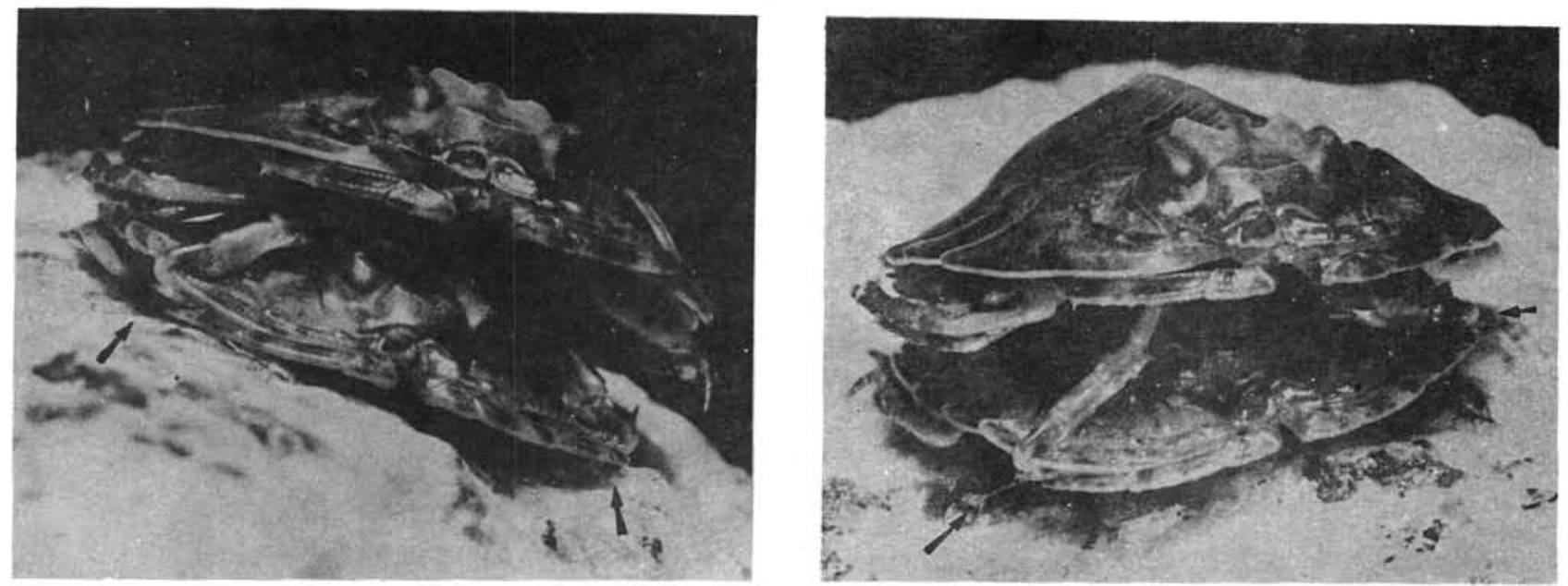

Figs 4-5 - Serolis polita, adult male, $15.5 \mathrm{~mm}$ long, and pre-adult female, $15.0 \mathrm{~mm} 10 \mathrm{ng}$. Copulatory position, showing distinctly the pereopod II clasping the lateral margins of the first segment of the female. The others pereopods are not used in holding the female.
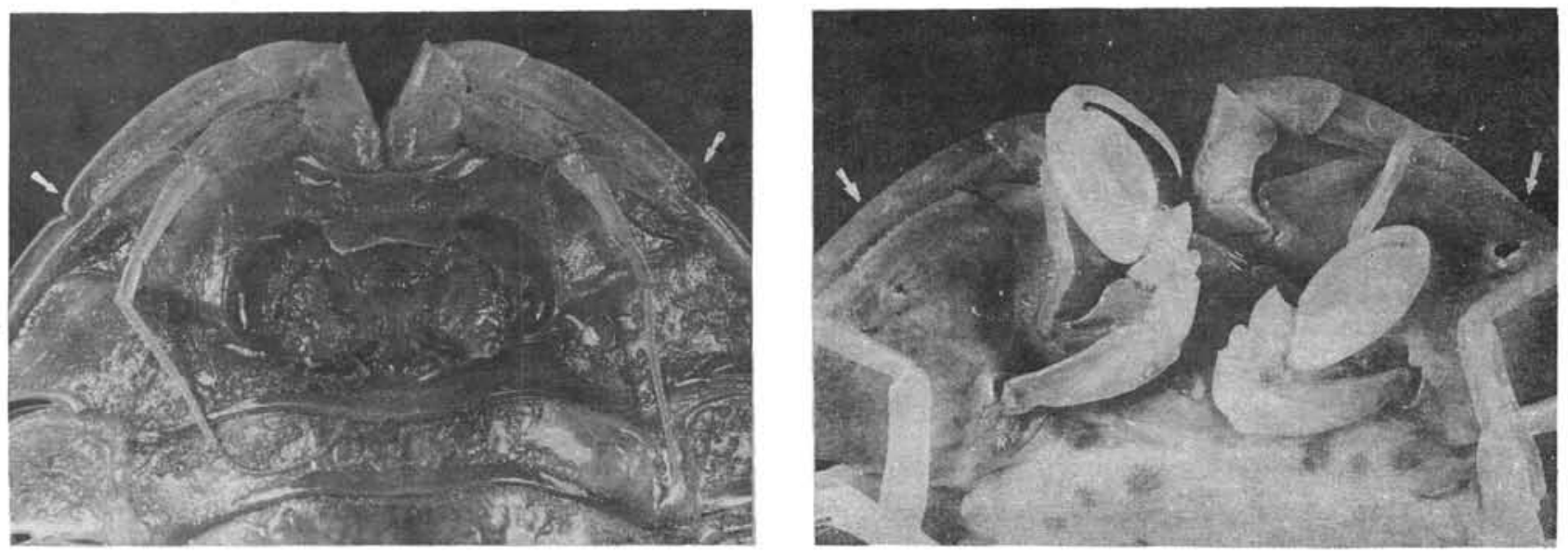

Fig. 6-Serolis meridionalis, female with developing oostegites, 48.0 mm 1 ong. Anterodorsal view showing the sores on the lateral portions of the first segment. These sores are caused by the subchela of the male clasping appendages.

Fig.? - Serolis trilobitoides, ovigerous female, $57.0 \mathrm{~mm}$ long. Antero-ventral view showing the holes in the lateral portions of the first segment. The holes were made by the subchela of the male clasping appendages. 
Both mature males and females of serolis polaris, as well as of Serolis Zaevis (Moreira, 1971b), do not ingest any kind of food during the breeding period.

Some experiments were performed in order to ascertain the feeding behavior of the mature specimens of both Serolis polaris and Serolis laevis. Severil kinds of food, alone or together in different combinations, such as morse 1 of molluscs, Laminaria sp. (seaweed very abundant nearby the collecting site), particulate organic matter, and small crabs, amphipods and polychaets, dead or alive, were offered to the animals. Serolis polaris as we 11 as Serolis laevis were never observed trying to gather any one or in combinations the foods offered. After many trials, it was concluded that both species do not ingest food during the breeding period.

Apparent changes in the behavior of Serolis polaris due to copulation were not noted. In other words, the animals continued to spend most of their time in the same place, moving only at night, and occasionally. Their movements continued lethargic. When walking during copulation, the males and females do so. The male carries the female beneath him using for locomotion the pereopods not used to hold the female. Due to end of the cruise it was not possible to observe the normal separation of the male from the female.

\section{DISCUSSION}

Bastida \& Torti (1970) reported their observations of live Serolis marplatensis and Serolis gaudichaudi. Their conclusions particularly on the aspects concerning the general behavior, basically agree with those expressed here for Serolis polaris. The authors did not note a higher activity at night for either serolis marplatensis and Serolis gaudichaudi. On the contrary, mature specimens of Serolis polaris are slightly more active at night than at daytime. The same was found to be true for Serolis Zaevis (Moreira, $1971 b$ ).

Accounts have been published showing that a same species may have different behavior at each developmental stage. Moreira (1973a-b and unpublished data), observed that Arcturezla sawayae present strikingly different behavior patterns during development. Young animals behave differently from gravid females or mature males. The author observed, too, that the behavior of adult females is different before and after breeding. Gravid females of some species of isopods not only diminish their movements but also change habitat and hide themselves (Naylor \& Quénisset, 1964). Other species may adopt a burrowing mode as observed for Lirceus fontinalis (= Asellus macrourus = Mancaselzus macrourus, in Hubricht \& Mackin, 1949 apud Markus, 1930), and suggested for species of Aega and Rocinela (Zimmer, 1927). 
The behavior reported for Serolis polaris refers to mature animals, at a uniform and wel1 characterized developmental stage (Table I). The young of both Serolis marplatensis and Serolis gaudichaudi in their first stages are more active and rapid than older specimens (Bastida \& Torti, 1970). The higher daytime activity reported for these two species can probably be explained by the difference in developmental stage.

The behavior of the females of Serolis polaris, escaping from the males in their attempts at copulation, is interesting and uncommon amongst isopods. The on ly reference that could be found to this sexual escape behavior was reported by Kjennerud (1952) for Idotea neglecta. Bastida \& Torti (1970) do not mention similar behavior in either serolis marplatensis or serolis gaudichaudi.

However, they have observed the mentioned position of copulation to be common in Serolis marplatensis, both between males and ovigerous females, as we 11 as, between two males. Sometimes they found three males in position of copulation over a same female.

Nordenstam (1933) after the examination of many specimens of Serolis, called attention to the fact that some ovigerous females, young and adult males, and females with developing oostegites, presented scars or marks produced by the subchela of the male pereopod II. Serolis polaris, males trying to copulate with ovigerous females or embryo bearing females was also but rarely observed. Similar cases such as those reported by Bastida \& Torti (1970) seem to confirm the observations of Nordenstam (1933). It might possibly be inferred from the cited observations that this behavior is common.

Probably, however, this deviant sexual behavior does not occur frequent $1 \mathrm{y}$ in the natural habitat of the species. It seems that such behavior may be stimulated by the aquarium conditions or from a complex series of factors, such as different sex ratio, crowding etc. It is well known that many species change their behavior when kept in aquariums.

Scars altering the shape of the pereonite $I$ of the female were already subject to consideration. Grube (1875) observed in specimens of Serolis paradoxa small transparent depressions at the marginal portions of the pereonite I, which he considered as sensory frontal organs. Beddard (1884) observed similar structures in many species of Serolis. He described them as narrow and deep, surrounded by a thick ring, and having a small central hole which he considered as a pore. However, it was Nordenstam (1933), followed by Sheppard (1933), who pointed out that such structures were derived from the thinness of the cuticle due to the rubbing movement of the dactylus of the male pereopod II.

Nordenstam (1933) considered these scars as "morphological features connected with copulation". As was already pointed out, these features are found in many species of Serolis. 
Species of Serolis show striking sexual dimorphism, particularly in regard to size and ornamentation of the pereopod II. In the male it is stout and subchelate, while in the female it is not subchelate and morphologically resembles the others pereopods (Fig. 2). In mature males such appendages show variable shapes (Fig. 3) and do not aid in the locomotion of the animal. Specifically it has the function of clasping and holding the female in the position of copulation.

Other species of isopods do not show this specialization. One or more pereopods can perform this specific clasping function. The male of Lirceus fontinalis hold the female with the $3 \mathrm{rd}$ pair of pereopods, helped sometimes by the 2nd and 4th (Markus, 1930). The male of Cassidinopsis maculata uses the 4 th pair, whose basipodite differs from the others because it is elongate and slightly recurved (Monod, 1930). Jaera albifrons males use the 5 th pair, and sometimes the $4 \mathrm{th}$ one also (Forsman, 1944). The males of Glyptonotus antarcticus hold the females by the margin of the pereon using the first three pairs of gnathopods (White, 1970).

The normal position of copulation within the isopods is similar to that described for Serolis polaris, e.g., the animals in copulation are orientated in the same direction (Unwin, 1920; Monod, 1930; Markus, 1930; Kjennerud, 1952). However, several cases have been observed departing from this general procedure. The male of Jaera albifrons hold the female dorsally, with the head over their pleotelson, i.e., in an inverted position (Forsman, 1944). Strouhal (1942) observed that Jaera italica mates with their ventral sides facing.

There is no fixed specific stage at which the males seek the females. There is, however, a close relation between the process of reproduction and the period of molting in the female. Generally, the males clasp the female when the posterior half of the cuticle has been cast (Markus, 1930; Kjennerud, 1952; Birstein, 1964). However, in some cases the males hold the female before molting has occurred (Nordenstam, 1933; White, 1970). In this case, often the males help the female in shedding their skin (Unwin, 1920; Markus, 1930). In our observations in Serolis polaris, the position of copulation was accomplished while the female was not molting, but it is highly probable that situations as described above are the commonest.

The total period that males and females remain in the copulatory position is variable. In Serolis polaris lasts more than 4 days. White (1970) has observed that in Glyptonotus antarcticus the male remains over the female about 190 days. In both Idotea neglecta (Kjennerud,1952) and Asellus aquaticus (Unwin, 1920) it lasts few days, or, as observed for the latter species, also may 1 ast on 1y few hours (Maercks, 1930; Birstein, 1964).

Males and females of many isopod species do not ingest any food once the sexual maturity is reached. This behavior has been confirmed for Idotea neglecta (Kjennerud, 1952), Mesidotea entomon (McCrimmon \& Bray, 1962), Naesa 
bidentata (Naylor \& Quénisset, 1964), Glyptonotus antarcticus (White, 1970), Arcturezza sawayae (Moreira, $1973 a$ and unpublished data) etc. In several Sphaeromatidae genera, as for instance, in Naesa, Cymodoce, Dynamene and Cerceis, the oral appendages of females that reach maturity degenerate, at the same time that the ingestion of food is suspended (Hansen, 1905; Silva, 1963; Naylor \& Quēnisset, 1964).

Our observations confirm that both adult males, gravid females, as well as animals in copulation of Serolis polaris, do not ingest any kind of food, in spite of the variety of food offered to them. Similar behavior was discussed for Serolis laevis (Moreira, 1971b) and Serolis marplatensis, whose gravid females drastically reduce the ingestion of food or simply ignore it (Bastida \& Torti, 1970).

RESUMO

0 presente trabalho relata as observações sobre o comportamento reprodutivo de Serolis polaris Richardson, 1911. Informaçoes correlatas adicionais, obtidas pelo exame de grande número de espécies, complementam diversos aspectos relacionados a eventos que ocorrem na época da reprodução. Descrevese o comportamento pré-copulatório, assim como, a posição de copulação. Fêmeas pré-adultas apresentam comportamento de escape à aproximação inadequada dos machos, em suas tentativas de copulação. O pereópodo II é o apêndice que mantem a fêmea em posição de copulação, daí apresentar modificações morfológicas adaptadas à execução dessa função específica. Cicatrizes e anomalias diversas podem ser produzidas nas fêmeas pela subquela do pereópodo II do macho. Numerosas experiências demonstraram que machos e fêmeas não mais se alimentam ao atingirem a maturação sexual. Finalmente, os diversos aspectos do comportamento reprodutivo são detalhada e amplamente discutidos.

\section{ACKNOWLEDGEMENTS}

I would like to express my thanks to Prof. Dr. Paulo Sawaya, Director, Instituto de Biologia Marinha, University of São Paulo, for reading critically the manuscript. Special thanks also to Mr. Frank F. Shaffer for the correction of the English text. 


\section{REFERENCES}

BASTIDA, R. \& TORTI, M.R. 1970. Crustaceos Isopodos: Serolidae. Résult. scient. Camp. Calypso, no IX. Annls Inst. oceanogr. Monaco, n.s., 47: 61-105.

BEDDARD, F.E. 1884. Report on the Isopoda collected by H.M.S. Cha1lenger during the years 1873-76. Part I. The genus Serolis. In: Thompson, C.W. \& Murray, J. - Rep. scient. Results Voy. H.M.S. Challenger, zool., $11: 1-85$, p $1 \mathrm{~s} 1-10$.

BIRSTEIN, Ya. A. 1964. Fauna of U.S.S.R. Crustacea, 7 (5). Fresh-water is opods (Ase11ota). Zoo1. Inst. Acad. Sci. U.S.S.R., n. ser., (47):1-148 (English translation).

BOCQUET, CH. 1953. Recherches sur le polymorphisme nature1 des Jaera marina (Fabr.) (Isopodes, Ase1lotes): essai de systematique evolutive. Arch. Zool. exp. gén., 90:187-450.

BOWMAN, T.E. 1960. Description and notes on the biology of Lironeca puhi n. sp. (Isopoda: Cymothoidae), parasitic of the Hawaiian moray ee 1, Gymnothorax eurostus (Abbot). Crustaceana, 1 (2):84-91, p1. 2 .

DO CHI, T. 1970. Écologie des étangs 1ittoraux de la région des sables d'0llonne. Trav. Fac. Sci. Rennes, sér. Océanogr. biol., (4):3-113.

FISH, S. 1970. The biology of Eurydice pulchra (Crustacea: Isopoda). J. mar. biol. Ass. U.K., 50:753-768.

FORSMAN, B. 1944. "Beobachtungen über Jaera albifrons Leach an der schwedischen Westküste. Ark. Zoo1., 35 A (11):1-33, p1. 1.

GRUBE, E.A. 1875. Beitrag zur Kenntniss der Gattung Serolis und einer neuen Art derselben. Arch. Naturgesch., 61 (1):208-284.

HANSEN, H.J. 1905. On the propagation, structure and classification of the family Sphaeromidae. Q. J1 microsc. Sci., n.s., 49:69-135.

HESSLER, R.R. 1967. A record of Serolidae (Isopoda) from the North At lantic Ocean. Crustaceana, 12 (2):159-162.

1970. A new species of Serolidae (Isopoda) from bathyal depths of the Equatoria1 At 1antic 0cean. Crustaceana, 18 (3):227-232.

HOWES, N.H. 1939. Observations on the biology and pos-embryonic development of Idotea viridis (Slabber) (Isopoda, Valvifera) from New England Creek, South-east Essex. J. mar. biol. Ass. U.K., 23:279-310.

HUBRICHT, L. \& MACKIN, J.G. 1949. The fresh-water isopods of the genus Lirceus (Ase11ota, Ase11idae). Amer. Mid1. Nat., 42 (2):334-349, p1s 1-3.

JONES, D.A. 1970. Populations densities and breeding in Eurydice pulchra and Eurydice affinis in Britain. J. mar. biol. Ass. U.K., 50:635-655.

KINNE, 0. 1954. Eidonomie, Anatomie und Lebenszyklus von Sphaeroma hookeri Leach (Isopoda). Kieler Meeresforsch., 10 (1):100-120.

KJENNERUD, J. 1952. Ecological observations on Idotea neglecta G.0. Sars. Univ. Bergen Arb. (Naturv. rekke), 7:1-47. 
MAERCKS , H.H. 1930. Sexualbiologische Studien an AselZus aquaticus L. Zoo1. Jb., a11g. Zoo1. u. Physio1., 48:273-319.

MARKUS, H.C. 1930. Studies on the morphology and life history of the isopod, Mancasellus macrourus. Trans. Amer. microsc. Soc., 49 (3):220236, p 1.26 .

MCCRIMMON, H. \& BRAY, J. 1962. Observations on the isopod Mesidotea entomon in the Western Canadian Arctic Ocean. J. Fish. Res. Bd Can., 19 (3) : $489-496$.

MONOD, TH. 1930. Notes isopodologiques. 3. Sur un Cassidinopsis peu connu des Iles Kerguelen. Bu11. Soc. Zool. France, 55 (5):437-446.

MOREIRA, P.S. 1966. Sobre espécies da família Serolidae (Isopoda, F1abe 11 ifera) do litoral norte do Estado de São Paulo. Tese de Doutoramento. Universidade de São Paulo, 175 p., 30 ests, 10 tabs.

\section{Brazil. Bolm Inst. oceanogr., S Paulo, 20 (1):85-144, p1s 1-20.}

1971b. Fisioecologia de isöpodes do gênero Serolis Leach, 1818 (Crustacea, Serolidae). Tese de Livre Docência. Universidade de são Pau1o, 297 p. + at las.

1973a. Behavioral aspects of Arcturella sawayae Moreira, 1973 (Crustacea, Isopoda, Valvifera). Bolm Zool. Biol. mar., N.S., (30):217-232.

$1973 b$. Food and feeding behavior of Arcturelza sawayae Moreira, (Crustacea, Isopoda, Valvifera).Bolm Zoo1. Biol. mar., N.S., (30):217-232.

1973c. Biologia de Serolis completa bellifera). I. Estádios de desenvolvimento. S Pau1o, 22:93-108.
(Crustacea, Is opoda, FlaBo $1 \mathrm{~m}$ Inst. oce anogr.,

1974 .

Cryptic protective coloration of Serolis laevis and Serolis polaris (Isopoda, Flabe11ifera). Crustaceana, 27 (1):1-4, p1. 1 .

An account of the Serolidae (Crustacea, Isopoda, F1abe11ifera) collected by U.S. Antarctic Expedition. Antarctic Res. Ser. (in press).

NAYLOR, E. 1955. The 1ife cycle of the isopod Idotea emarginata (Fab.). J. Anim. Ecol., 24 (2):270-281.

\& QUENISSET, D. 1964. The habitat and life history of Naesa bidentata (Adams). Crustaceana, 7 (5):212-216.

NORDENSTAM, A. 1933. Marine Isopoda of the families Serolidae, Idotheidae, Pseudidotheidae, Arcturidae, Parasellidae and Stenetriidae mainly from the South At lantic. Further zool. Results Swed. Antarct. Exped., 3 (1):1-284, p 1 s $1-2$.

SHEPPARD, E. 1933. Isopoda Crustacea. Part I. The family Serolidae. "Discovery" Rep., 7:253-362, p1. 14.

SILVA, J.L. e 1963. Metamorfoses das peças bucais em fêmeas de Cymodoce Leach, 1814. Bolm Inst. Defesa Patrim. Nat., zool., (5):1-10.

STROUHAL, H. 1942. Vörlaufige Mitteilung uber die von M. Beier in Nordwestgriechen 1 and gesamme1ten Asse1n. Zool. Anz., 138:145-162.

UNWIN, E.E. 1920. Notes upon the reproduction of Aselzus aquaticus. J. Linn. Soc., Zoo1., 34:335-343.

WHITE, M.G. 1970. Aspects of the breeding biology of Glyptonotus antarcticus (Eights) (Crustacea, Is opoda) at Signy Is 1 and, South Orkney Is 1 ands. In: Holdgate, M.W., ed. - Antarctic ecology. London, Academic Press, vo1. $1: 279-285$. 
WOLFF, T. 1962. The systematics and biology of bathyal and abyssal Isopoda Ase11ota. Galathea Rep., 6:1-320, p1s 1-19.

ZIMMER, C. 1927. Is opoda - Asse1n. Handb. Zoo1., 3 (1):697-766. 